OPEN ACCESS

Edited by:

Sunjoo Kang,

Cheju Halla University, South Korea

Reviewed by:

Carlos Teixeira Brandt, Federal University of Pernambuco,

Pradeep Nair Central University of Himachal Pradesh, India

*Correspondence:

Una E. Maclntyre

Una.MacIntyre@up.ac.za

Specialty section: This article was submitted to Public Health Education and Promotion,

a section of the journal Frontiers in Public Health

Received: 14 September 2018 Accepted: 05 February 2019 Published: 12 March 2019

Citation:

Bello TK, Gericke GJ and MacIntyre UE (2019) Development,

Implementation, and Process Evaluation of a Theory-Based Nutrition

Education Programme for Adults Living With HIV in Abeokuta, Nigeria.

Front. Public Health 7:30

doi: 10.3389/fpubh.2019.00030

\section{Development, Implementation, and Process Evaluation of a Theory-Based Nutrition Education Programme for Adults Living With HIV in Abeokuta, Nigeria}

\author{
Temitope K. Bello, Gerda J. Gericke and Una E. MacIntyre* \\ Department of Human Nutrition, Faculty of Health Sciences, University of Pretoria, Pretoria, South Africa
}

Introduction: Healthy diets play a role in the management and care for adults living with HIV/AIDS (ALH). Appropriate nutrition education (NE) is necessary to equip ALH with relevant knowledge and skills for healthy eating. A needs assessment identified the need for a nutrition education programme (NEP) as part of the nutrition service for ALH in Abeokuta, Nigeria. The aim of this study was to design a theory-based NEP and to evaluate the implementation process among ALH attending selected federal and state hospitals in Abeokuta as out-patients.

Materials and Methods: An exploratory descriptive needs assessment in the qualitative and quantitative domains was conducted among a convenient sample of ALH ( $N=243)$ at the selected hospitals. The quantitative needs assessment identified needs for improvement in the primary outcome [quality of life (QoL)] and the secondary outcomes [quality of dietary intake, nutrition knowledge, attitudes, and practice (KAP), and anthropometric status]. Participants' perceptions of the NEP were obtained using an interviewer administered questionnaire among $70 \mathrm{ALH}$ who attended the implementation of the NEP and process evaluation thereof at the intervention hospital.

Results: The qualitative results identified a lack of knowledge on planning varied meals with limited resources. The identified needs, existing guidelines and literature were integrated with appropriate constructs of the Social Cognitive Theory (SCT) and the Health Belief Model (HBM) into the NEP. The NE manual, participant's work book, flipcharts, and the brochure were tailored to address the identified challenges.

Discussion: The process evaluation showed that the NEP was implemented as planned and that the participants' perceptions were positive. The use of the NE manual, participant's work book, flipcharts, and brochure demonstrated the practicality of incorporating behavioral theories in NE for ALH.

Keywords: HIV, behavioral theories, nutrition education, quality of life, nutrition education resources, program development, nutrition 


\section{INTRODUCTION}

A healthy diet should be part of the management of adults living with HIV/AIDS (ALH). Nutrition education (NE) has been found to improve the quality of life (QoL) and general well-being of ALH (1-3). The World Health Organization (WHO) (4) and American Dietetic Association (ADA) (5) in their resolution have urged nutrition and dietetics experts globally to give thoughtful attention to the NE of ALH to improve their health status (4). Research evidence has shown that antiretroviral therapy (ART) and micronutrient and macronutrient supplements alone, without nutrition education (NE), cannot reduce morbidity and mortality rates associated with HIV-infections (3).

Nutrition behaviors of people cannot be easily changed without identification of the mediators of their behavior (6). Appropriate alignment of an intervention to address the mediators of behavior can enhance intervention efficacy ( 7 , 8). The constructs of learning theories in behavior based education have revealed success not only for fruit and vegetable consumption (9), but also for HIV prevention, smoking cessation (10), and other health behaviors. Behavioral theories are valuable in informing the development and implementation of a nutrition education programme (NEP) and in providing an understanding of the basis for the success or failure of interventions $(6,8,11)$.

There seems to be no recent literature reporting on the development and implementation of a NEP for ALH to improve QoL, nutritional knowledge, individual dietary diversity scores (IDDS), and anthropometric status. In health behavioral education research, the Social Cognitive Theory (SCT), Health Belief Model (HBM), Social Network or Support Theory, Theory of Planned Behavior or Reasoned Actions (TPB or TRA) and Trans Theoretical Model or Stages of change (TTM or SC) are the most established and commonly used theories $(12,13)$.

The joint United Nations Programme on HIV/AIDS (UNAIDS) reports confirmed that the mortality rate related to
HIV and AIDS diseases is high in developing countries such as Nigeria where application of an existing national guideline on nutritional care and support for people living with HIV/AIDS (PLWHA) seems to be inadequate (14). Hence, NE aimed at providing ALH with adequate nutrition knowledge needed for healthy dietary practices and improved QoL should be considered $(3,15)$. The aim of this study was to design a theory-based NEP and to evaluate the implementation process among the ALH attending selected federal and state hospitals in Abeokuta.

\section{NEEDS ASSESSMENT FOR THE DEVELOPMENT OF THE NUTRITION EDUCATION PROGRAMME}

\section{Study Design}

A cross sectional exploratory and descriptive study design in the quantitative and qualitative domains was used for the needs assessment.

\section{Population and Sampling}

Convenience sampling was used to recruit 243 males and females (18-50 years; on ART for $\geq 3$ months but $\leq 5$ years) from the selected hospitals out-patient departments after obtaining ethical approval from Faculty of Health Science Research Ethics Committee, University of Pretoria (South Africa), and the two selected hospitals in Abeokuta.

\section{Data Collection}

Previously validated questionnaires were used to obtain quantitative data in respect of QoL (16), nutrition KAP (17-19) and dietary quality using the IDDS (20). Anthropometric status (body mass index (BMI), triceps skinfolds and midupper arm circumference) was measured using standard

TABLE 1 | Summary of participants' needs identified from the needs assessment.

\begin{tabular}{|c|c|c|c|}
\hline Variable & $\mathbf{N}$ & Results & Needs identified \\
\hline QoL & 169 & $\begin{array}{l}\text { Mean scores in physical functioning }(47 \%) \text {, role limitation due to physical } \\
\text { health }(46 \%) \text { and role limitation due to emotion }(56 \%) \text { cannot be considered } \\
\text { as good }(16,19)\end{array}$ & QoL was poor \\
\hline Nutrition knowledge & 235 & $\begin{array}{l}\text { Mean scores for knowledge: meal planning (33\%), food preparation (54\%), } \\
\text { food purchasing }(50 \%) \text {, and general nutrition knowledge }(49 \%)\end{array}$ & $\begin{array}{l}\text { Poor nutrition knowledge and need } \\
\text { for NE }\end{array}$ \\
\hline Dietary diversity & 206 & $\begin{array}{l}\text { Overall dietary diversity of the participants was poor; } 134(65 \%) \text { had IDDS of } \\
\leq 4 \text {. Food groups not consumed by } 42 \% \text { or more of participants: dark } \\
\text { green vegetables, }(42 \%) \text { vitamin A rich fruits and vegetable }(42 \%) \text {, other } \\
\text { fruits and vegetables }(62 \%) \text {, legumes and nuts ( } 49 \%) \text { organ meats }(100 \%) \text {, } \\
\text { milk and milk products }(79 \%) \text {, and eggs and egg products }(74 \%)\end{array}$ & Unvaried diets and food insecurity \\
\hline Anthropometric status & 228 & $\begin{array}{l}\text { Mean BMI }\left(24 \mathrm{~kg} / \mathrm{m}^{2}\right), \text { MUAC (for wasting }<22 \mathrm{~cm} \text { for female and }<23 \mathrm{~cm} \\
\text { for male) and TSF }(31.3 \mathrm{~mm}) \text { were within the range associated with good } \\
\text { health, but } 22 \% \text { were overweight, } 14 \% \text { obese and } 8 \% \text { underweight }\end{array}$ & $\begin{array}{l}\text { Guidance to maintain anthropometric } \\
\text { status associated with good health }\end{array}$ \\
\hline
\end{tabular}

QoL, Quality of life; KAP, Knowledge, attitudes and practices; BMI, Body mass index; MUAC, Mid upper arm circumference; IDDS, Individual' dietary diversity score. 
TABLE 2 | Nutrition education programme content.

\begin{tabular}{|c|c|c|}
\hline Week & Lesson & Content description \\
\hline 1 & $\begin{array}{l}\text { Understanding HIV/AIDS } \\
\text { and the impact on health } \\
\text { and nutritional status }\end{array}$ & $\begin{array}{l}\text { - What is HIV and AIDS? } \\
\text { - What is the immune system? } \\
\text { - What are the symptoms of HIV/AIDS? } \\
\text { What are the modes of transmission of } \\
\text { - What is the impact of HIV/AIDS on } \\
\text { health and nutritional status? }\end{array}$ \\
\hline 2 & Management of HIV/AIDS & $\begin{array}{l}\text { - Drug therapy including the interaction } \\
\text { with nutrients } \\
\text { - Dietary management and nutritional } \\
\text { care in HIV/AIDS management }\end{array}$ \\
\hline 3 & $\begin{array}{l}\text { Guidelines on good } \\
\text { nutrition: well-planned } \\
\text { varied meals }\end{array}$ & $\begin{array}{l}\text { - Good nutrition and well-planned varied } \\
\text { meals based on classes of food } \\
\text { - Importance of good nutrition }\end{array}$ \\
\hline 4 & $\begin{array}{l}\text { Guidelines on good } \\
\text { nutrition: well-planned } \\
\text { varied meals continued }\end{array}$ & $\begin{array}{l}\text { - Nigerian guidelines on nutritional care } \\
\text { and support for people living with } \\
\text { HIV/AIDS }\end{array}$ \\
\hline 5 & $\begin{array}{l}\text { Good nutrition: Planning } \\
\text { well planned varied meals } \\
\text { continued }\end{array}$ & $\begin{array}{l}\text { - Group planning of well-planned varied } \\
\text { meals based on available foods and } \\
\text { resources }\end{array}$ \\
\hline 6 & $\begin{array}{l}\text { Good nutrition: } \\
\text { management of nutrition } \\
\text { related problems during HIV } \\
\text { infections }\end{array}$ & $\begin{array}{l}\text { - Nutritional problems and how to deal } \\
\text { - with them: } \\
\text { - Weight loss } \\
\text { - Diarrhea } \\
\text { - Fever } \\
\text { - Anemia }\end{array}$ \\
\hline 7 & Tips for positive living & $\begin{array}{l}\text { - Tips for positive living (medication and } \\
\text { foods). } \\
\text { - Food handling: animal products, fruits } \\
\text { and vegetables } \\
\text { - General hygiene } \\
\text { - Importance of exercise/physical } \\
\text { activities for positive living in HIV/AIDS }\end{array}$ \\
\hline 8 & Quality of life and HIV & $\begin{array}{l}\text { - What is QoL? } \\
\text { - Who is responsible for your QoL? } \\
\text { - How to improve your QoL? }\end{array}$ \\
\hline 9 & $\begin{array}{l}\text { Dealing with barriers to } \\
\text { healthy eating }\end{array}$ & $\begin{array}{l}\text { - Facilitate group discussion on } \\
\text { overcoming barriers to healthy eating }\end{array}$ \\
\hline 10 & $\begin{array}{l}\text { Management of food } \\
\text { budget and purchasing }\end{array}$ & $\begin{array}{l}\text { - Describe the purpose of meal planning } \\
\text { - Describe tips for shopping } \\
\text { - Describe how to use limited budgets for } \\
\text { healthy foods }\end{array}$ \\
\hline 11 & Revision & \\
\hline 12 & $\begin{array}{l}\text { Question time and } \\
\text { evaluation }\end{array}$ & $\begin{array}{l}\text { Obtain participants feedback on: } \\
\text { - Experience with training components } \\
\text { - Experience with the duration of } \\
\text { education programme } \\
\text { - Perceptions on overall NEP delivery } \\
\text { quality and benefits }\end{array}$ \\
\hline
\end{tabular}

AIDS, Acquired immunodeficiency syndrome; SCT, Social cognitive theory; HBM, Health belief model; HIV, Human immunodeficiency syndrome; NEP, Nutrition education programme; QoL, Quality of life; TB, Tuberculosis.

techniques $(21,22)$. Data collection instruments were translated into the local language, Yoruba, according to recommended procedures (23).

Four focus group discussions (FGDs) (20 participants) were held until data saturation was reached to explore participants' dietary patterns.

\section{Data Analysis}

Descriptive statistics were used to describe the participants' demographic data. The elements (construct/subscales) of QoL, KAP, IDDS, and anthropometric status were summarized by sex using frequencies. Stata statistical software (release 10, 2007) was used for all quantitative analyses. The thematic framework approach was used to analyse the qualitative data (24).

\section{Challenges Identified by the Needs Assessment}

The need for the development of the NEP to improve the QoL, nutrition KAP, IDDS, and anthropometric status of ALH was identified (Table 1). The quantitative results were complemented by the FGDs results.

\section{DEVELOPMENT OF THE NUTRITION EDUCATION PROGRAMME}

The development process was guided by the steps for designing a theory-based NEP as described by Sahyoun et al. (25) and Contento (26). The nutrition education content and materials are summarized in Tables 2, 3 .

The trainer's manual and participant's work book were designed to cover topics addressing the problems identified during the needs assessment.

The flipcharts consisted of 15 charts adapted from existing charts (27-30) and were used to create visual connections, provide cues to action and motivate participants to adopt healthier behaviors (Table 3).

The brochure summarized the manual by covering all the problems identified in the needs assessment (e.g., impact of HIV/AIDS on health and the nutritional status of the people living with HIV/AIDS and dietary management of HIV).

\section{IMPLEMENTATION AND PROCESS EVALUATION OF NUTRITION EDUCATION PROGRAMME}

\section{Study Design}

The implementation was part of a quasi-experimental design in which one of the two sites was randomly allocated to the implementation to evaluate the impact of the NEP on QoL, nutrition KAP, IDDS, and anthropometric status. Participants at the intervention site received face to face group teaching of the NEP with the education materials over 12 weeks. The process was evaluated at the end of week 12 .

\section{Population and Sample}

The target population comprised ALH attending the study sites as out patients. The overall mean score for the QoL scale for the needs assessment was $65 \%( \pm 14.7)$ indicating that a sample of at least 50 participants would have $90 \%$ power to detect an improvement of $10 \%$ in the QoL construct scores of the intervention group $(p=0.05)$. A drop out of $50 \%$ was considered 
TABLE 3 | Theory-based strategies and practical applications in educational activities.

\begin{tabular}{|c|c|c|}
\hline Strategies & Theoretical construct used & Application \\
\hline \multirow[t]{2}{*}{$\begin{array}{l}\text { Use of flipcharts during the } \\
\text { training session }\end{array}$} & $\begin{array}{l}\text { HBM } \\
\text { - Cue to action } \\
\text {-Perceived severity }\end{array}$ & $\begin{array}{l}\text { - Encourage participants to act on cues to healthy behavior } \\
\text { - Connect participants to reality by showing pictures on the flipcharts } \\
\text { - Give practical insights on the possible risk factors associated with HIV/AIDS such as: } \\
\text { wasting, TB, diabetes, cardiovascular diseases }\end{array}$ \\
\hline & $\begin{array}{l}\text { SCT } \\
\text { - Behavioral capability }\end{array}$ & $\begin{array}{l}\text { - Provide behavioral capability through provision of sufficient information needed to apply } \\
\text { knowledge }\end{array}$ \\
\hline Use of work book & $\begin{array}{l}\text { HBM } \\
\text { - Perceived barriers } \\
\text { SCT } \\
\text { - Self-efficacy } \\
\text { - Behavioral capability } \\
\text { - Outcome expectation }\end{array}$ & $\begin{array}{l}\text { - Assist participants to acquire skills and knowledge to overcome emotional and financial } \\
\text { barriers } \\
\text { - Build self-confidence when participants respond correctly to questions } \\
\text { - Initiate group interaction during the education sessions to give room for involvement of peers } \\
\text { - Encourage participants to discuss challenges and how to overcome them } \\
\text { - Develop participants' skills to plan varied meals with limited resources }\end{array}$ \\
\hline $\begin{array}{l}\text { Use of trainer's manual for one } \\
\text { on one teaching }\end{array}$ & $\begin{array}{l}\text { HBM } \\
\text { - Cue to action } \\
\text { - Perceived barriers } \\
\text { SCT } \\
\text { - Self-efficacy } \\
\text { - Behavioral capability } \\
\text {-Outcome expectation }\end{array}$ & $\begin{array}{l}\text { - Engage participants in one on one discussions to help them to identify healthy and unhealthy } \\
\text { dietary behaviors } \\
\text { - Expose individuals to cue for good adherence and reasons for poor adherence } \\
\text { - Facilitate group discussions to enhance acquisition of knowledge } \\
\text { - Write on the board and show flipchart pictures to facilitate participants' acquisition of } \\
\text { knowledge }\end{array}$ \\
\hline $\begin{array}{l}\text { Assessment of participants' prior } \\
\text { knowledge and revision of } \\
\text { previous lessons }\end{array}$ & $\begin{array}{l}\text { SCT } \\
\text { - Self-efficacy } \\
\text { - Behavioral capability }\end{array}$ & $\begin{array}{l}\text { - Participants' feedback to improve their self-confidence in performing acquired skills and } \\
\text { knowledge } \\
\text { - Encourages participants to demonstrate the knowledge they acquired through response }\end{array}$ \\
\hline
\end{tabular}

HIVIAIDS, HIV-Human immunodeficiency syndrome; AIDS, Acquired immunodeficiency syndrome; SCT, Social cognitive theory; HBM, Health belief model; TB, Tuberculosis.

for the intervention group; therefore a sample of at least 100 participants per group was appropriate.

The participants were stratified according to the duration on ART (0-24 months > 24 months) and sex during recruitment. Stratification for sex was based on the results of the needs assessment (25\% males: $75 \%$ females) to ensure that the sample was representative of the population sex distribution. The stratification of participants according to the duration on ART was to control for the confounding factor of ART.

\section{Implementation}

Intervention participants were allocated on a first come first served basis to groups of 13-15 participants per group. Each group met once a week for 12 weeks, and 60 minutes per session was planned and achieved.

The researcher (TKB), a registered nutritionist, facilitated most of the NE sessions with the assistance of trained research assistants. The NE sessions were conducted between Monday and Friday.

A separate venue, from where the participants received ART, was secured for the implementation. The intervention and control participants were given a brochure at the point of recruitment.

\section{Process Evaluation}

A questionnaire containing eight open ended questions developed by the researcher was administered to the intervention group at week 12 to obtain the participants' perceptions of the programme in terms of the reach, fidelity, length of the education sessions and whether personal expectations were met $(26,31)$.

\section{Data Analysis}

The quantitative data were analyzed using descriptive statistics (percentages and frequencies). The intervention participants' responses to the opened ended questions were analyzed using the thematic framework method of analysis $(24,32,33)$. The main themes that emerged were discussed in categories which included participants' perceptions of the NEP.

\section{RESULTS}

A total of 100 participants was allocated to seven NE groups. Table 4 shows the NE attendance rate (reach) during the education sessions over 12 weeks. The reasons for not achieving $100 \%$ attendance included death, bereavement, accident, no longer interested, work obligations, relocation to other areas, no response to reminder calls and family challenges.

Tables 5 summarizes the perceptions of the participants on the impact and presentation of the NEP on their knowledge and behavior.

\section{DISCUSSION}

The participants' retention rate was 77\% (in attendance for $\geq 50 \%$ of the weekly education sessions) at week 12 . This is higher than the results reported by Hatsu et al. (34) and Keithley et al. (35). Hatsu et al. (34) observed that 57\% of the intervention participants attended more than $50 \%$ of the education sessions. Keithley et al. (35) reported that $52 \%$ of the intervention group was available for the week 24 assessment in a 12 month randomized control trial among 90 ALH in Chicago. The high retention rates in our study could be explained in 
TABLE 4 | Summary of the intervention group attendance rate during the implementation of the nutrition education programme.

\begin{tabular}{lccc}
\hline & $\boldsymbol{n}$ & $\begin{array}{c}\text { Attendance of } \\
\mathbf{5} \mathbf{5} \% \text { of the weekly } \\
\text { education sessions } \\
\boldsymbol{n}(\%)\end{array}$ & $\begin{array}{c}\text { Drop-out } \\
\boldsymbol{n}(\%)\end{array}$ \\
\hline Group 1 & 15 & $11(73.3)$ & $4(26.7)$ \\
Group 2 & 15 & $12(80)$ & $3(20)$ \\
Group 3 & 15 & $11(73.3)$ & $4(26.7)$ \\
Group 4 & 15 & $12(80)$ & $3(20)$ \\
Group 5 & 13 & $11(84.6)$ & $2(15.4)$ \\
Group 6 & 14 & $8(57.1)$ & $6(42.9)$ \\
Group 7 & 13 & $12(92.3)$ & $1(7.7)$ \\
Total & 100 & 77 & 23 \\
\hline
\end{tabular}

n, number; drop-out, participants not available at week 12 assessments.

terms of enthusiasm and appreciation of the participants. The fact that participants might not have received any nutrition education materials related to HIV-infections prior to the present study might be a motivational factor for good attendance rates. Fortnightly telephonic reminders and encouragement given to participants to attend the next hospital appointment and nutrition education session could also have contributed.

The process evaluation showed that the programme delivery rate was $100 \%$ as had been planned. This result is in agreement with a study among ALH in the US that reported 100\% NEP delivery rates (34). In that study each of the four nutrition education sessions was delivered by a registered nutritionist for 45-60 min on the same day to two groups with 15 participants per group (34).

The NEP was based on the identified needs (Table 1). Hence, various topics such as guidelines on good nutrition via wellplanned varied meals and tips for positive living were part of the lessons (Table 2). The information on varied meals and strategies for medication adherence could be responsible for the desirable response from the participants that they learnt that planning meals containing a variety of foods is not necessarily expensive and daily intake of their medication is advantageous to their health status. Therefore, identification of the participants needs and addressing them can lead to positive perceptions toward behavioral change $(12,13,36)$.

Perceived severity is a construct of the HBM, understood as the possible perception that individuals have about their health status (37), and based on the beliefs and knowledge of an individual (37). The NEP informed participants of the consequences of eating unvaried diets such as weight loss, overweight, anemia, fatigue, and poor immunity. Flipchart pictures were used to contextualize the reality of the severity of the virus. ALH were informed of a study in the United States that reported that adherence to ART enhanced long term viral suppression and increase survival (38). The participant's belief that adherence to ART could delay and reduce the severity of HIV disease progression could promote positive behavior change.

A perceived barrier explains an individual's perception about the obstacles to adopting a new behavior (39). Participants' direct quotes showed that participants perceived barriers such as cost of healthy food were well addressed: "even with my limited resources varieties of foods could still be consumed." Adherence rates can be improved when barriers are addressed (38). The HBM perceived barrier construct was addressed by teaching participants on how to deal with barriers to healthy eating and sharing tips on food budgeting and purchasing.

Cues to action are events, people or things that can make people change their behavior (39), e.g., brochures, teaching, media reports, advice, and group interactions (36). A nutrition brochure, the participant's work book and flipcharts were used to provide cues to action. Participants had the opportunity to interact with peers and the facilitator of the NEP for nutrition guidance. Participants' direct quotes on tips for positive living, strategies for medication adherence, and tips for shopping and meal planning revealed that the education materials provided cues to action which could lead to behavior change (Table 5).

Behavioral capability entails knowledge and skills required to perform appropriate behaviors (40). In this study, it was expected that participants would acquire the nutrition knowledge and attitudes needed to embrace behavioral capability. The strategy of reinforcing information through the use of the NE materials was applied (41). Participants' direct quotes that they learnt planning varieties of meals even with limited resources revealed behavioral capability (Table 5).

A perceived benefit is a personal opinion or an individual's conclusion on a new behavior and can lead to adoption of healthier behaviors (37). The NE materials emphasized that varied foods are needed for proper functioning of the immune system and good QoL. Participants' responses on take home messages such as regular exercise, avoidance of fatty foods and eating of varieties on a daily basis showed that participants acquired knowledge based on perceived benefits (Table 5).

Self-efficacy is an individual's boldness or self-confidence to perform newly acquired skills (42). This construct of the SCT was facilitated by engaging participants in revision of previous lessons with inputs from the participants. Participants were also engaged in role playing on planning a healthy meal with limited resources. Participants were asked questions such as descriptions of foods available in their environment, tips for positive living, and prior knowledge of management of HIV/AIDS in order to enhance their self-confidence. The self-efficacy construct was successfully used in an 8 week community based NEP for 40 low-income adults in Seattle to improve fruit and vegetable consumption (43).

The participants in this study were expected to have positive change of attitudes by performing appropriate nutrition actions in order to improve QoL. The outcome expectation construct was incorporated into the NE materials through an explicit explanation on the benefits of good nutrition during HIV-infections. Participants' direct quotes that the education sessions were informative and timely could be responsible for the positive responses of knowledge acquisition (Table 5). Participants' perceptions of the benefits of good nutrition could enhance their readiness to adopt a healthy nutrition lifestyle (44). 
TABLE 5 | Summary of the perceptions of the participants on the impact and presentation of the nutrition education programme.

\begin{tabular}{|c|c|c|}
\hline Theme & Sub-theme & Participants quotes \\
\hline \multicolumn{3}{|l|}{ IMPACT } \\
\hline Participants' expectations & Participants' personal expectations being met & "Yes the training met my expectations because I learnt new things" \\
\hline New knowledge & New things learnt during the programme & "Yes I learn something new" \\
\hline \multirow[t]{7}{*}{$\begin{array}{l}\text { New knowledge that participants } \\
\text { anticipate implementing }\end{array}$} & $\begin{array}{l}\text { Nutrition recommendations and medication side } \\
\text { effects }\end{array}$ & $\begin{array}{l}\text { "That we should not add extra salt to our foods after preparation" } \\
\text { "I learnt that I should first take my medication before eating" } \\
\text { "I learnt that patients on Efavirenz should avoid too much of starchy foods" }\end{array}$ \\
\hline & Strategies for medication adherence & $\begin{array}{l}\text { "I learnt that I should take my medication at the right time" } \\
\text { "I learnt that we should not smoke cigarette" } \\
\text { "I learnt that I should not miss my clinical appointment" } \\
\text { "I learnt that I should not drink alcohol" }\end{array}$ \\
\hline & Quality of life & $\begin{array}{l}\text { "I learnt that my quality of life can be improved by accepting that challenges of } \\
\text { life are to help me grow" } \\
\text { "I learnt that whatever I eat can affect my emotions (moods)" } \\
\text { "I learnt that I can live long by eating varieties, taking medications and worrying } \\
\text { less" } \\
\text { "I learnt personal hygiene can help me improve my quality of life" }\end{array}$ \\
\hline & Benefits of eating variety of food & $\begin{array}{l}\text { "I learnt that eating varieties can enhance nutrient adequacy" } \\
\text { "We learnt that we should eat different varieties of foods because they will make } \\
\text { our body to function well" } \\
\text { "I learnt that I don't need to be rich to eat varieties, even with my limited } \\
\text { resources I can still eat varieties" } \\
\text { "I learnt that in planning my daily menu, fruits should be given daily consideration" } \\
\text { "I learnt we should eat varieties of foods during pregnancy" }\end{array}$ \\
\hline & Tips on planning meal on a limited budget & "It pays to plan our meals and make budget for food purchase" \\
\hline & Tips for positive living & $\begin{array}{l}\text { "I learnt about good ways of living with my status such as personal hygiene" } \\
\text { "I learnt that to stay healthy, I need regular exercise" }\end{array}$ \\
\hline & Tips for shopping & "I learnt that I should buy healthy foods" \\
\hline \multirow{2}{*}{$\begin{array}{l}\text { Overall impact of the education } \\
\text { sessions }\end{array}$} & Impact of medications on health status & "I have learnt to use my medication every day" \\
\hline & Take home messages & $\begin{array}{l}\text { "I learnt that too much of fatty foods should be avoided" } \\
\text { "I learnt that we should not eat food that contain lots of fats" } \\
\text { "Budget making" } \\
\text { "I have learnt how to plan varieties of meals with limited resources" } \\
\text { "I learnt that street foods are not the best for me" } \\
\text { "I learnt about eating right" }\end{array}$ \\
\hline
\end{tabular}

\section{PRESENTATION}

Understanding of the NEP

Learning challenges during the education sessions

Length of the education session

Adequate understanding of the NEP

Needs more education sessions

Adequacy of the duration of education sessions

Recommendations

General comments

\section{"Yes"}

"None"

"I understood everything"

"The time was ok"

"I want the duration to be extended"

"The time was well managed"

"The time was too short for the education sessions"

"The education session should continue"

"The facilitator really came down to the level of the participants"

"The education sessions were good and useful to us"

"The teaching sessions were interesting and informative"

NEP, Nutrition education programme.

Incorporation of the selected constructs of the SCT and HBM in the development of the NE materials could be responsible for the acquisition of new knowledge. Another NEP used the SCT to improve fruit and vegetable intakes among 754 out-patients in rural Virginia (45). The study indicated significant improvement in knowledge of fruit and vegetable consumption among the intervention group (45). Heim et al. (46) also implemented a 12 weeks garden based NEP that was planned by using the constructs of the SCT and experiential learning theories among children with low fruit and vegetable intakes in the US, leading to significant increase in their fruits and vegetables intake (46).

The participants' perceptions of the presentation of the programme showed that the education sessions were informative and interesting. Several factors may have contributed to these positive responses. Experts have confirmed that the facilitator, the mode and the format of NE delivery play a vital role in the 
effectiveness of the implementation of a NEP (26). The use of group education which was reported to be easier, cheaper and to require less skill or professionalism than individual counseling (26) could also have contributed to the acquisition of knowledge.

\section{CONCLUSION}

The results of the needs assessment informed the necessity for the development of the NEP. The use of well-planned education content and materials (flipcharts, brochure and participant's work book) and teaching of NE by a registered nutritionist could be responsible for the positive feedback received in the present study.

\section{ETHICS STATEMENT}

Ethical permission for the study was sought from the Faculty of Health Sciences Research Ethics Committee, University of Pretoria, South Africa (number: 311/2014) and from the two hospitals (Hospital 1: FMCA/470/HREC/2014; Hospital 2: SHA.144/vol. II/97). Permission to access the participants'

\section{REFERENCES}

1. Kaye HL, Moreno-Leguizamon CJ. Nutrition education and counselling as strategic interventions to improve health outcomes in adult outpatients with HIV: a literature review. Afr J AIDS Res. (2010) 9:271-83. doi: $10.2989 / 16085906.2010 .530183$

2. UNAIDS. Global Report: UNAIDS Report on the Global AIDS Epidemic. (2013). Available online at: http://www.unaids.org/sites/default/files/media_ asset/UNAIDS_Global_Report_2013_en_1.pdf

3. Grobler L, Siegfried N, Visser ME, Mahlungulu SS, Volmink J. Nutritional interventions for reducing morbidity and mortality in people with HIV. Cochrane Database Syst Rev. (2013) 28:CD004536. doi: 10.1002/14651858.CD004536.pub3

4. World Health Organization. Nutrient Requirements for People Living With HIV/AIDS: Report of a Technical Consultation. (2003), p. 1-31. Available online at: https://www.who.int/nutrition/publications/hivaids/9241591196/ en/

5. Fields-Gardner C, Campa A. Position of the American Dietetic Association: nutrition intervention and human immunodeficiency virus infection. J Am Diet Assoc. (2010) 110:1105-19. doi: 10.1016/j.jada.2010. 05.020

6. Contento IR. Nutrition Education: Linking Research, Theory, and Practice. 2nd ed. New York, NY: Jones and Bartlett (2011).

7. Lippke S, Ziegelmann JP. Theory-based health behavior change: developing, testing, and applying theories for evidence-based interventions. Appl Psychol. (2008) 57:698-716. doi: 10.1111/j.1464-0597.2008.00339.x

8. Rothman AJ. Is there nothing more practical than a good theory? Why innovations and advances in health behavior change will arise if interventions are used to test and refine theory. Int J Behav Nutr Phys Activity. (2004) 1:11. doi: 10.1186/1479-5868-1-11

9. Thomson CA, Ravia J. A systematic review of behavioral interventions to promote intake of fruit and vegetables. J Am Diet Assoc. (2011) 111:1523-35. doi: 10.1016/j.jada.2011.07.013

10. Wiefferink CH, Peters L, Hoekstra F, Ten Dam G, Buijs GJ, Paulussen TG. Clustering of health-related behaviors and their determinants: possible consequences for school health interventions. Prev Sci. (2006) 7:127-49. doi: 10.1007/s11121-005-0021-2

11. Michie S, Prestwich A. Are interventions theory-based? Development of a theory coding scheme. Health Psychol. (2010) 29:1. doi: 10.1037/a0016939 medical records was obtained from the Chief Executive Officers (CEO) of the two hospitals. No participant was allowed to participate without understanding and signing the informed consent for the study in a manner conforming with the declaration of Helsinki. Confidentiality and freedom to withdraw from the study at any time without prejudice were assured.

\section{AUTHOR CONTRIBUTIONS}

TB, GG, and UM were involved in the conception and research design of the study. TB supervised recruitment of participants and data collection. GG and UM participated in the data analysis. All authors were involved in the interpretation of the data and the writing of the of the paper. All authors approved the final version of the paper.

\section{ACKNOWLEDGMENTS}

The support received from the Department of Research and Innovation (DRI) of the University of Pretoria, Tertiary Education Trust Funds (TET Funds), and Red Cross International Lagos branch are well valued.

12. Painter JE, Borba CP, Hynes M, Mays D, Glanz K. The use of theory in health behavior research from 2000 to 2005: a systematic review. Ann Behav Med. (2008) 35:358-62. doi: 10.1007/s12160-008-9042-y

13. Glanz K, Bishop DB. The role of behavioral science theory in development and implementation of public health interventions. Annu Rev Public Health. (2010) 31:399-418. doi: 10.1146/annurev.publhealth.012809. 103604

14. UNAIDS. Global AIDS Update 2016. (2016). Available online at: http://www. unaids.org/sites/default/files/media_asset/global-AIDS-update-2016_en.pdf

15. Canadian AIDS Treatment Information Exchange. A Practical Guide to Nutrition for People Living with HIV. (2007). p. 1-63. Available online at: https://www.catie.ca/sites/default/files/40012.pdf

16. Rands Health. Medical Outcomes Study: 36-Item Short Form Survey Instrument. (2009). Available online at: https://www.rand.org/health-care/ surveys_tools/mos/36-item-short-form.html

17. Whati L, Senekal M, Steyn N, Nel J, Lombard C, Norris S. Development of a reliable and valid nutritional knowledge questionnaire for urban South African adolescents. Nutrition. (2005) 21:76-85. doi: 10.1016/j.nut.2004.09.011

18. Anand D, Puri S. Nutritional knowledge, attitude, and practices among HIV-positive individuals in India. J Health Popul Nutr. (2013) 31:195-201. doi: 10.3329/jhpn.v31i2.16383

19. Oketch JA, Paterson M, Maunder EW, Rollins NC. Too little, too late: comparison of nutritional status and quality of life of nutrition care and support recipients and non-recipients among HIV-positive adults in KwaZulu-Natal, South Africa. Health Policy. (2011) 99:267-76. doi: 10.1016/j.healthpol.2010.08.018

20. Food and Agriculture Organization of the United Nations. Food Based Dietary Guidelines for Adults and Children Over the Age of Seven Years. (2009). Available online at: http://www.fao.org/ag/humannutrition/ nutritioneducation/fbdg/49849/en/nga/

21. National Health and Nutrition Examination Survey (NHANES). Anthropometry Procedures Manual. (2000). Available online at: https:// www.cdc.gov/nchs/data/nhanes/nhanes_07_08/manual_an.pdf

22. Gibson RS. Principles of Nutritional Assessment. 2nd ed. New York, NY: Oxford University Press (2005).

23. World Health Organization. Process of Translation and Adaptation of Instruments. (2010). Available online at: http://www.who.int/substance_ abuse/research_tools/translation/en/. 
24. Ritchie J, Spencer L. Qualitative Data Analysis for Applied Policy Research. 2nd ed. New York, NY: Sage publications (2002). p. 305-29.

25. Sahyoun NR, Pratt CA, Anderson A. Evaluation of nutrition education interventions for older adults: a proposed framework. J Am Diet Assoc. (2004) 104:58-69. doi: 10.1016/j.jada.2003.10.013

26. Contento IR. Nutrition Education: Linking Research, Theory, and Practice. New York, NY: Jones and Bartlett (2007). p. 491.

27. Zambia Counseling Flipcharts. Eating and Living Well-Good Nutrition Makes a Difference for People Living with Illness. (2017). Available online at: https://www.fantaproject.org/sites/default/files/resources/ZambiaNutrition-Flipchart-June2017.pdf

28. World Health Organisation. Flipchart for Patient Education: HIV Prevention, Treatment and Care. (2006). Available online at: https://www.who.int/hiv/ pub/imai/flipchart.pdf?ua=1

29. Onimawo I. Nigerian traditional food system and nutrition security: International Scientific Symposium Biodiversity and Sustainable Diets United Against Hunger. (2010). Available online at: http://www.fao.org/ag/ humannutrition/25375-02fe454548959127d5a0ea3af260d945e.pdf

30. Maziya-Dixon B. Nigeria Food Consumption and Nutrition Survey, 2001-2003: Summary. Ibadan: International Institute of Tropical Agriculture (2004).

31. Steckler AE, Linnan LE. Process Evaluation for Public Health Interventions and Research. San Francisco, CA: Jossey-Bass (2002).

32. Stewart H, Gapp R, Harwood I. Exploring the alchemy of qualitative management research: Seeking trustworthiness, credibility and rigor through crystallization. Qual Rep. (2017) 22:1-19. Available online at: https:// nsuworks.nova.edu/tqr/vol22/iss1/1

33. Gale NK, Heath G, Cameron E, Rashid S, Redwood S. Using the framework method for the analysis of qualitative data in multidisciplinary health research. BMC Med Res Methodol. (2013) 13:117. doi: 10.1186/1471-2288-13-117

34. Hatsu I, Campa A, Johnson P, Huffman F, Thomlison B, Baum M. Nutrition education intervention for low-income human immunodeficiency virus-infected adults. J Behav Health (2014) 3:161-8. doi: 10.5455/jbh.20140726034114

35. Keithly JK, Swanson B, Zeller JM, Sha BE, Cohen M, Hershow R, et al. Comparison of standard and immune-enhancing oral formulas in asymptomatic HIV-infected persons: a multicenter randomized controlled clinical trial. J Parenter Enteral Nutr. (2002) 26:6-14. doi: 10.1177/014860710202600106

36. Glanz K, Rimer BK, Viswanath K. Health Behavior and Health Education: Theory, Research, and Practice. 4th ed. San Francisco, CA: John Wiley \& Sons (2008).
37. Sharma M. Theoretical Foundations of Health Education and Health Promotion. Burlington, MA: Jones \& Bartlett Publishers (2016).

38. Initiation of and Adherence to Treatment as Prevention. CDC (2013) Available online at: http://www.cdc.gov/hiv/prevention/programs/pwp/art.html

39. Skinner CS, Tiro J, Champion VL. The health belief model. Health Behavior: Theory, Research, and Practice. San Francisco, CA: John Wiley \& Sons (2015). p.75-94.

40. Lee J, Jeong S, Ko G, Park H, Ko Y. Development of a food safety and nutrition education program for adolescents by applying social cognitive theory. Osong Public Health Res Perspec. (2016) 7:248-60. doi: 10.1016/j.phrp.2016.05.005

41. Goh LML, Goh LML, Wong AXY, Wong AXY, Ang GY, Ang GY, et al. Effectiveness of nutrition education accompanied by cooking demonstration. Br Food J. (2017) 119:1052-66. doi: 10.1108/BFJ-10-2016-0464

42. Eldredge LKB, Markham CM, Kok G, Ruiter RA, Parcel GS. Planning Health Promotion Programs: an Intervention Mapping Approach. San Francisco, CA: John Wiley \& Sons (2016).

43. Ko LK, Rodriguez E, Yoon J, Ravindran R, Copeland WK. A brief communitybased nutrition education intervention combined with food baskets can increase fruit and vegetable consumption among low-income latinos. J Nutr Educ Behav. (2016) 48:609-17.e1. doi: 10.1016/j.jneb.2016.06.010

44. Eldredge LKB, Markham CM, Ruiter RA, Kok G, Parcel GS. Planning Health Promotion Programs: an Intervention Mapping Approach. San Fransisco, CA: John Wiley \& Sons (2016).

45. Carcaise-Edinboro P, McClish D, Kracen AC, Bowen D, Fries E. Fruit and vegetable dietary behavior in response to a low-intensity dietary intervention: the rural physician cancer prevention project. J Rural Health. (2008) 24:299305. doi: 10.1111/j.1748-0361.2008.00172.x

46. Heim S, Stang J, Ireland M. A garden pilot project enhances fruit and vegetable consumption among children. J Am Diet Assoc. (2009) 109:1220-6. doi: 10.1016/j.jada.2009.04.009

Conflict of Interest Statement: The authors declare that the research was conducted in the absence of any commercial or financial relationships that could be construed as a potential conflict of interest.

Copyright (c) 2019 Bello, Gericke and MacIntyre. This is an open-access article distributed under the terms of the Creative Commons Attribution License (CC BY). The use, distribution or reproduction in other forums is permitted, provided the original author(s) and the copyright owner(s) are credited and that the original publication in this journal is cited, in accordance with accepted academic practice. No use, distribution or reproduction is permitted which does not comply with these terms. 